\title{
Effect of vitamin A deficiency on the content of three forms of vitamin $A$ in hen's eggs
}

\author{
By P. A. PLACK, W. S. MILLER AND C. M. WARD \\ Unit for Biochemical Research bearing on Fisheries' Problems* and Nutrition \\ Department, National Institute for Research in Dairying, Shinfield, Reading \\ (Received 7 fanuary 1964-Accepted 28 Fanuary 1964)
}

In the ripe eggs of all species of marine teleost fish so far examined, retinal (vitamin A aldehyde) is the predominant form of vitamin $A$, and in some species it represents $90 \%$ of the total vitamin A-active material in the eggs (Plack, Kon \& Thompson, 1959; Plack \& Kon, 196I). Hen's eggs also contain retinal and, for forty-one eggs from six hens on a diet of breeder's mash, a value of $2 \mathrm{I} \cdot 7 \mu \mathrm{g} / \mathrm{egg}$ was obtained, representing I $3 \%$ of the total vitamin A (Plack, 1963). The predominance of retinal in fish eggs suggests that it may be of importance in the development of the embryo. With hens, an increased intake of vitamin $A$ results in increases in the retinal, retinol esters and retinol contents of eggs (Plack, I963) and we show here that vitamin A-depleted birds lay eggs containing reduced amounts of the three forms of vitamin $A$. The retinal content did not become predominant under conditions of vitamin A deficiency, as might have been expected if it were of particular significance for the development of the embryo.

\section{EXPERIMENTAL}

Animals. Forty Light Sussex pullets, hatched on 21 September 1962, were reared in a brooder for 7 weeks on a starter's diet, the composition of which is shown in Table I. All three diets used were made in the Institute. No vitamin A was added to the diet but provitamin A carotenoids were present, largely in the dried grass. At 7 weeks of age, the birds were transferred to an outside ark with a grass run and given the grower's diet (Table I). Initially, no vitamin A was added to the diet but the birds would have derived a certain amount of carotene from the grass they ate; the amount of grass available during the winter of $1962-3$, however, was very small. One bird from the flock was killed each week and its liver content of vitamin A determined. For the period from 5 November 1962 to 4 February 1963 liver stores varied between 40 and $\mathrm{I} 200 \mu \mathrm{g}$, mean value $380 \mu \mathrm{g}$. To increase the reserves, the diet was supplemented from 7 February 1963 with $32 \mu \mathrm{g}$ vitamin A/100 g diet as Rovimix 325 A (Roche Products Ltd) and from 8 March 1963 the vitamin A supplement was increased to $50 \mu \mathrm{g} / \mathrm{l} 00 \mathrm{~g}$, given as a vitamin A concentrate (Crookes Laboratories Ltd) in arachis oil.

The birds came into lay in the middle of March and on 2 April 1963 six were transferred to single battery cages. Eggs for analysis were collected regularly from 20 April I 963 , when they each weighed more than $5 \circ \mathrm{g}$. On 29 April 1963 the birds were given

- Grant-aided by the Development Fund. 
the layer's diet (Table I) containing, per $100 \mathrm{~g}$, about $2 \mu \mathrm{g}$ vitamin A, probably in the fish meal, and $5 \mu$ g carotenes, together with small amounts of provitamin A (cryptoxanthin) in the xanthophylls, derived from the wheat and oats.

Determination of vitamin $A$. One egg from each of the six birds was analysed each week the day after it was laid, except when egg-laying was irregular and the egg laid last had to be used, after a maximum of 4 days' storage in a refrigerator. Eggs laid between those taken for immediate analysis were stored in deep-freeze and some were analysed during the next 4 months.

$\begin{array}{lccc}\text { Table I. Percentage composition of the experimental diets } \\ & \text { Starter's } & \text { Grower's } & \text { Layer's } \\ \text { Maize } & 35 & 35 & \circ \\ \text { Wheat } & 30 & 35 & 60 \\ \text { Oats } & 0 & 0 & 22.5 \\ \text { Wheat middlings } & 9 & 16 & 0 \\ \text { Fish meal } & 10 & 5 & 10 \\ \text { Dried skim milk } & 7.5 & 3 & \circ \\ \text { Dried grass } & 3 & 0 & 0 \\ \text { Dried brewer's yeast } & 3 & 3 & 3 \\ \text { Ground limestone } & 1.5 & 1.25 & 2.5 \\ \text { Bone meal } & 0 & 0.83 & 1 \cdot 0 \\ \text { Salt mixture } & 0.5 & 0.42 & 0.5 \\ \text { Arachis oil, containing } 63.4 & 0.5 & 0.5 & 0.5 \\ \text { i.u. vitamin } \mathrm{D}_{8} / 0.5 \mathrm{~g} & & & \end{array}$

- Composition: $\mathrm{MnSO}_{4} \cdot 4 \mathrm{H}_{2} \mathrm{O} 6.0 \%, \mathrm{KI} 0.06 \%, \mathrm{NaCl}_{93} .94 \%$.

Eggs and livers were treated and retinal, retinol esters and retinol determined in them as described by Plack (1963), except that with livers the Carr-Price test for retinal was done in the cell of a recording spectrophotometer (Plack \& Kon, I96r). With extracts of livers from vitamin A-depleted birds, the Carr-Price reaction on the retinal fractions yielded no colour but the solutions had absorption curves falling in extinction from 500 to $840 \mathrm{~m} \mu$, so that the method of calculation of Plack \& Kon (196I) gave 'values' for retinal concentration. The presence of retinal was accepted only when a peak, or inflexion, at about $666 \mathrm{~m} \mu$ was present in the absorption curve. The extraction of blood plasma and determination of the three forms of vitamin $A$ were by the methods of Plack, Miller \& Ward (to be published).

\section{RESULTS}

Liver reserves of vitamin A of the six experimental birds at the time egg collection was begun were estimated from analyses of livers of five birds from the same flock. Four of them had less than I $\mathrm{mg}$ vitamin $\mathrm{A}$ in the liver, but one had stores approaching $3 \mathrm{mg}$.

The numbers of eggs laid by the six birds are given in Table 2. Bird no. 4 was in lay for about 2 weeks longer than the other pullets, which suggests that it had a higher liver reserve initially. Regular egg-laying ceased relatively abruptly and occasional eggs were then laid at irregular intervals.

The birds all appeared to be healthy, but two died suddenly in the course of the 
Table 2. Numbers of eggs laid by the six birds during the period of collection

\begin{tabular}{lllllll} 
& \multicolumn{7}{c}{ Bird no. } \\
\cline { 2 - 6 } \multicolumn{1}{c}{ Period } & I & 2 & 3 & 4 & 5 & 6 \\
20-26 April & 6 & 6 & 7 & 5 & 6 & 6 \\
27 April-3 May & 5 & 7 & 6 & 5 & 6 & 7 \\
4-10 May & 2 & 7 & 3 & 5 & 6 & 6 \\
1 1-17 May & 4 & 2 & 5 & 7 & 5 & 7 \\
18-24 May & 4 & 1 & 4 & 5 & 5 & 5 \\
25-3 1 May & $0 *$ & 1 & 1 & 5 & 2 & 2 \\
1-7 June & - & $0 \dagger$ & 0 & 5 & 0 & 0 \\
8-13 June & - & - & 0 & 1 & 0 & 1
\end{tabular}

- Died 28 May. $t$ Died 2 June.

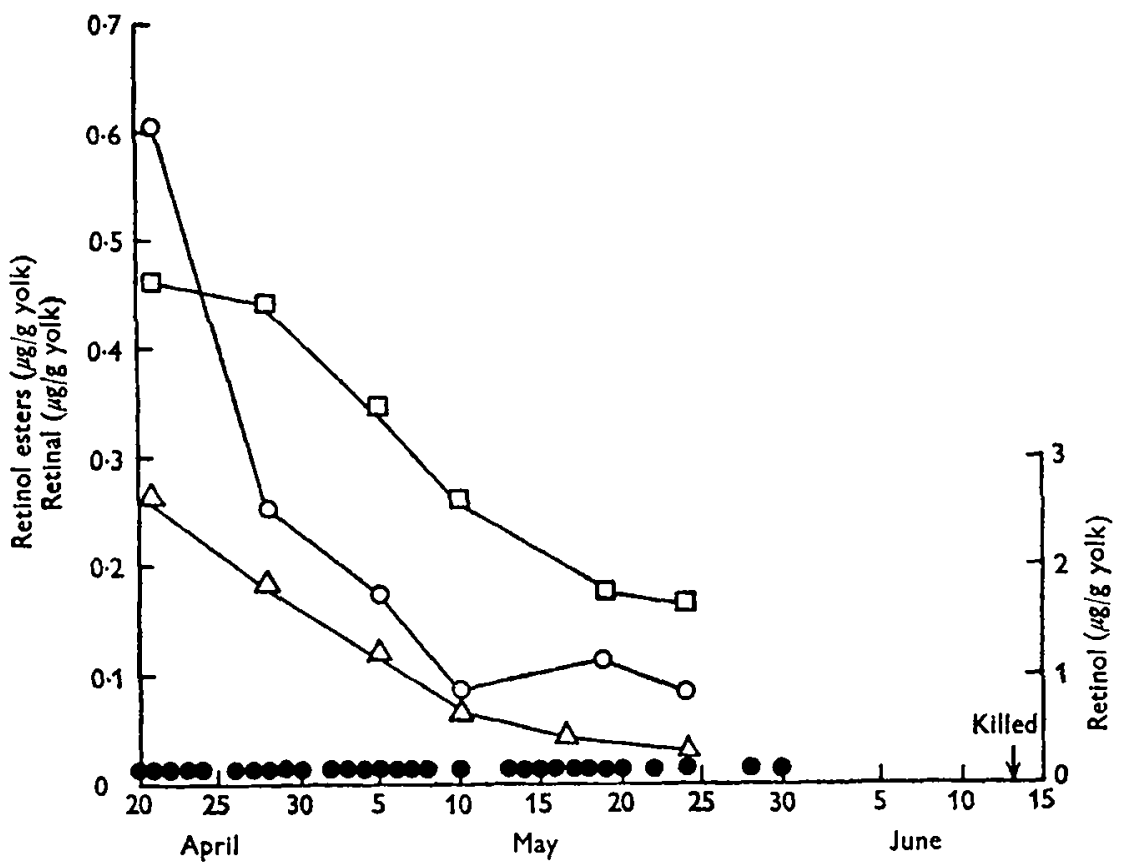

Fig. 1. Eggs (•) laid by bird no. 5 and concentrations of retinal (०- 0 ), retinol esters $(\square-\square)$ and retinol $(\Delta-\Delta)$ in their yolks from 20 April 1963 , when the eggs weighed more than $50 \mathrm{~g}$.

experiment, 3 and 5 days after an egg was laid. A post-mortem examination on bird no. I, kindly carried out by the Houghton Poultry Research Station, revealed 'signs indicative of vitamin A deficiency'. The other four birds were killed on 13 June 1963 so that blood samples could be obtained. For two of them there were intervals of 15 and 13 days between the time of laying the last egg and killing; bird no. 6 laid an egg the day before it was killed, otherwise the interval would have been 17 days, and bird no. 4 continued laying until 3 days before it was killed.

Analyses of eggs from the six birds showed that, in eggs laid on the same day, the vitamin A concentrations in the yolk were markedly different. The results for the six birds could not therefore effectively be combined and Fig. I gives the concentrations 
of retinal, retinol esters and retinol for bird no. 5. Results for the other birds, when plotted in the same way, showed similar falls in the concentrations of the three forms of vitamin A but, particularly for bird no. 4, a displacement of the time scale. Analyses of deep-frozen eggs gave values which lay on curves parallel to, but below, those of Fig. I indicating, as expected, a loss of vitamin A on storage; these results have not

Table 3. Vitamin A composition of eggs from normal hens and from a vitamin A-depleted bird

Egg weight (g)

Yolk weight (g)

Total vitamin A $(\mu \mathrm{g} / \mathrm{egg})$

Total vitamin A ( $\mu \mathrm{g} / \mathrm{g}$ yolk)

Retinal (\% of total)

Retinol esters (\% of total)

Retinol (\% of total)

$\begin{array}{cc}\begin{array}{c}\text { Beginning } \\ \text { of expt } \\ (21 \text { April) }\end{array} & \begin{array}{c}\text { End of } \\ \text { expt } \\ (24 \mathrm{May})\end{array} \\ 57.5 & 59.8 \\ 15.6 & 20.0 \\ 57.6 & 11.3 \\ 3.6 & 0.56 \\ 16 & 15 \\ 13 & 29 \\ 71 & 56\end{array}$

- From Plack (1963).

Table 4. Lipid, retinal, retinol esters and retinol in the livers and plasma of the birds at the end of the experiment

\begin{tabular}{|c|c|c|c|c|c|}
\hline & \multicolumn{5}{|c|}{ Bird no. } \\
\hline & $2 *$ & 3 & 4 & 5 & 6 \\
\hline Liver: & & & & & \\
\hline Weight (g) & $58 \cdot 9$ & $5^{6 \cdot 3}$ & $62 \cdot 2$ & $40 \cdot 7$ & $60 \cdot 4$ \\
\hline Lipid (\%) & 5.9 & .77 & $20 \cdot 1$ & $8 \cdot 5$ & 13.8 \\
\hline Retinal ( $\mu \mathrm{g} /$ liver) & 0 & $\circ$ & 0 & $\circ$ & 0 \\
\hline Retinol esters ( $\mu \mathrm{g} /$ liver $)$ & $9 \cdot 7$ & 6.0 & $8 \cdot 5$ & 3.6 & $16 \cdot 0$ \\
\hline Retinol ( $\mu \mathrm{g} /$ liver $)$ & 44 & 6.0 & $12 \cdot 0$ & 3.8 & $9 \cdot 6$ \\
\hline Plasma: & & & & & \\
\hline Lipid $(\mathrm{g} / 100 \mathrm{ml})$ & $--\cdot$ & $I \cdot 6$ & $2 \cdot 2$ & $2 \cdot 1$ & $I \cdot 4$ \\
\hline Retinal $(\mu \mathrm{g} / 100 \mathrm{ml})$ & - . & $\circ$ & $\circ$ & 0 & 0 \\
\hline Retinol esters $(\mu \mathrm{g} / \mathrm{r} 00 \mathrm{ml})$ & $\ldots$ & $1 \cdot 2$ & 0.7 & 0.9 & $1 \cdot 2$ \\
\hline Retinol $(\mu \mathrm{g} / 100 \mathrm{ml})$ & $-\cdots$ & $1 \cdot 6$ & $3 \cdot 0$ & $2 \cdot 6$ & $3 \cdot 0$ \\
\hline
\end{tabular}

- Bird died, no blood sample obtained.

been considered. From 21 April to 24 May 1963 the weight of eggs laid by bird no. 5 varied between $53^{\circ} 2$ and $59^{\circ} . \mathrm{g}$ and showed an overall slight increase. The weight of the yolks increased over this period from 15.6 to $20.0 \mathrm{~g}$ but the percentage of dry matter remained constant $(50 \cdot 0-52 \cdot 6 \%)$ as did the percentage of lipid $(33 \cdot 4-38 \cdot 1 \%)$.

Table 3 gives the proportions of the three forms of vitamin A in eggs collected at the beginning and end of the experiment. The percentage of retinal remained constant, but the percentage of retinol esters increased and that of retinol decreased. The concentrations of all three forms, however, decreased, as shown in Fig. 1 .

Examination of the livers and blood plasma at the end of the experiment gave no indication of the presence of retinal, but small amounts of retinol esters and retinol were found in both tissues (Table 4 ). 


\section{DISCUSSION}

In this experiment we have attempted to raise pullets on a diet providing sufficient vitamin A for normal development but not enough for accumulation of large liver stores. The liver reserves when egg-laying began were a little lower than we had planned but, by delaying the change to the diet almost completely deficient in vitamin $A$, the birds were kept in lay for about 10 weeks and a period of 5 weeks was available when the pullets were producing eggs of weight in excess of $50 \mathrm{~g}$.

The concentrations in eggs of the three forms of vitamin A, retinal, retinol esters and retinol, fell steadily during the first part of the experiment but towards the end the concentrations of retinal and retinol esters became steady, and that of retinol decreased more slowly (Fig. I). This levelling off may have been in part due to the limitations of the experimental technique, which is less sensitive when the three forms of vitamin A are determined separately than when retinol esters and retinol are determined together by a direct saponification procedure. Throughout the experiment, retinol was the predominant form of vitamin A in eggs, and there was no indication from its concentration in yolk that retinal was of importance in the development of the embryo.

In a previous paper (Plack, 1963 ) the effect of high doses of vitamin A given to a hen on the vitamin A content of her eggs was followed. In this paper, the study has been extended to cover a period of vitamin A depletion. Under conditions of repletion and depletion, the concentrations of all three forms of vitamin $A$ varied above and below the values for normal birds receiving an adequate amount of vitamin $A$ in their diet (see Table 3). The hen does not appear to possess a mechanism for regulating the quantity of vitamin A laid down in each egg and the conclusion that emerges is that the deposition of vitamin A in eggs is a passive process, and that the quantities of the three forms present in eggs reflect their concentrations in the blood at the time of formation of the yolk. There is, however, evidence that the presence of retinal in blood is regulated in some way, probably by hormones. Mature cockerels have negligible concentrations of retinal in their blood plasma, whereas laying hens have about $8 \mu \mathrm{g} / \mathrm{roo} \mathrm{ml}$ and, with pullets, the appearance of retinal in the blood coincides with the marked increase in oviduct weight and the onset of egg-laying (Plack, Miller \& Ward, 1964).

Although we have not carried out tests on hatchability, other workers have found that, with birds on vitamin A-deficient diets, hatchability of the eggs is about the same as that of eggs from birds receiving sufficient vitamin A (Hill, Scott, Norris \& Heuser, I961; McClymont \& Hart, 1948). Hill et al. (1961) obtained eggs from vitamin Adepleted hens which contained as little as 0.7 USP units $(0.21 \mu \mathrm{g})$ of vitamin A/g yolk. Since their saponification method would have determined only retinol esters and retinol it seemed possible to us that larger amounts of retinal may have been present and used by the developing embryo. Our results refute this suggestion.

With hens, then, the mobilization of retinal in the blood coincident with the onset of egg-laying (Plack et al. 1964) does not tally with the apparent lack of significance of this form for the developing embryo, as shown by analyses of eggs. With the cod, 
however, a similar appearance of retinal in the blood (P. A. Plack, A. D. Woodhead and P. M. J. Woodhead, unpublished observations) results in a predominance of this form in the eggs of the mature ovary (Plack, Woodhead \& Woodhead, 1961). This predominance of the aldehyde form of vitamin $A$ in the eggs of the cod and of other marine teleost fish suggests that it may be of more importance for the development of the fish embryo than for the development of the chick.

'These results, and those of McClymont \& Hart (1948) pose the question of the function of vitamin $A$ in egg-laying. We killed our birds about 2 weeks after they ceased to lay eggs; McClymont \& Hart (1948) reported a period of $44.7 \pm 14.3$ days between cessation of egg production and natural death for twenty-two vitamin Adepleted birds. Presumably the birds had a small reserve of vitamin $A$ at the beginning of this period, so that egg-laying ceased before they were completely depleted of vitamin A. Since hatchability is not impaired by vitamin A deficiency (although further development of the chick may be), cessation of egg production may be a mechanism to avoid the production of non-viable offspring. On the other hand, a state of vitamin A deficiency in the mother bird may be reached such that some aspect of the formation of an egg is inhibited.

\section{SUMMARY}

I. Six Light Sussex pullets were raised on a diet low in vitamin A and provitamin A carotenoids and at the time egg-laying began they had liver reserves of about I $\mathrm{mg}$ vitamin $\mathrm{A}$.

2. Egg production continued for about ro weeks and ended relatively abruptly. Two birds died during the experiment and the other four were killed.

3. Eggs laid during the last 5 weeks of production were analysed for retinal, retinol esters and retinol and for total lipid. During this time, the percentage of lipid in the yolk remained constant but the content of total vitamin A decreased to about i $\mu \mathrm{g}$. In the total vitamin $\mathrm{A}$, the percentage of retinal remained roughly constant, but the percentage of retinol esters rose and that of retinol fell, although retinol was the predominant form throughout.

4. There was no indication that retinal was of particular importance for the development of the embryo.

We thank Dr M. E. Coates and the staff of the henhouse, Nutrition Department, National Institute for Research in Dairying, for their co-operation and Drs S. K. Kon and $\mathrm{S}$. Y. Thompson for guidance.

\section{REFERENCES}

Hill, F. W., Scott, M. L., Norris, L. C. \& Heuser, G. F. (196I). Poult. Sci. 40, 1245.

McClymont, G. L. \& Hart, L. (1948). Aust. vet, F. 24, 5.

Plack, P. A. (1963). Brit. F. Nutr. 17, 235.

Plack, P. A. \& Kon, S. K. (1961). Biochem. F. 81, 56r.

Plack, P. A., Kon, S. K. \& Thompson, S. Y. (1959). Biochem. Y. 7r, 467.

Plack, P. A., Miller, W. S. \& Ward, C. M. (1964). Biochem. $\mathcal{Y}$. 90, 38 P.

Plack, P. A., Woodhead, A. D. \& Woodhead, P. M. J. (1961). F. mar. biol. Ass. U.K. 41, 617. 